\title{
PENGEMBANGAN INDUSTRI NON-CORPORATE PARTISIPATIF INTEGRATIF PADA INDUSTRI MINYAK ATSIRI KENANGA
}

\author{
VINA SALVIANA DS \\ Jurusan Kesejahteraan Sosial, Fakultas Ilmu Sosial dan Ilmu Politik, Universitas Muhammadiyah Malang \\ E-mail: vina_salviana@yahoo.co.id
}

\begin{abstract}
ABSTRAK
Penelitian ini merupakan action research dengan yang mengangkat persoalan industri minyak Atsiri berbahan dasar bunga kenanga. Lokasi penelitian di Kabupaten Blitar adalah salah satu pusat produksi minyak Atsiri di Indonesia berpotensi untuk terus ditingkatkan produksinya pada skala internasional, oleh karena itu pemberdayaan masyarakat dengan model partisipatif integratif dengan membentuk kelompok usaha industri yang bersifat non-corporate menjadi alternatif pilihan yang dipandang tepat untuk komunitas petani bunga kenanga. Hasil penelitian ini adalah menyempurnakan proses destilasi minyak Atsiri kenanga, mengolah limbah industri penyulingan, membuat usaha minyak gosok/aroma teraphy serta meningkatkan mentalitas pelaku industri melalui pelatihan peningkatan motivasi bisnis.
\end{abstract}

Kata kunci: partisipatif integratif, industri non-corporate, action research, minyak atsiri

\begin{abstract}
This research is considered as 'action research' which was tried to analyze the problems of aetheric oil industry made of Cananga flower. Research was held in Blitar Regency, East Java, as one of center aetheric oil production in Indonesia, which has potential to increase its production up to international scale. Based on this perspective, it was important to build such community empowerment based on integrative-participative model through business industry groups with basic characteristic non-corporate as suitable alternative for the development of Cananga farmer community. The results of this research were enhance distilation process, dealing with the waste from the distilation process, expanding the business unit of aroma therapy as the main product and also improving business mentality through some training activity for business motivation building.
\end{abstract}

Key words: intergrative-participative, non-corporate industry, action research, aetheric oil

\section{PENDAHULUAN}

Pengembangan industri non-corporate partisipatif integratif adalah suatu model penelitian tindakan dengan sejumlah kegiatan penelitian yang ditujukan bagi industri yang berbasis masyarakat bukan manufaktur, sedangkan arti dari partisipatif integratif adalah model pemberdayaan yang melibatkan semua pihak baik bagian dari masyarakat, pelaku industri dan pemerintah. Minyak Atsiri merupakan salah satu di antara 32 komoditi prioritas nasional untuk dikembangkan dengan pendekatan cluster. Selain itu Indonesia merupakan salah satu negara produsen minyak Atsiri di dunia dan menghasilkan beberapa jenis minyak Atsiri yang mendominasi pasar dunia.

Kabupaten Blitar merupakan salah satu kabupaten di Indonesia yang melakukan pengembangan industri minyak Atsiri melalui Program Putri Kencana (Program Produk Unggulan Industri Kecamatan). Dalam pelaksanaannya, berbagai masalah menyebabkan industri tersebut sulit berkembang antara lain proses produksi minyak Atsiri masih menggunakan teknologi yang belum efisien dalam proses penyulingan baik berkaitan dengan waktu penyulingan yang terlalu lama dan juga tidak hemat bahan bakar, pengelolaan dan pemasarannya belum maksimal serta masih cenderung dikelola serta dipasarkan secara tradisional atau sederhana, belum adanya kerja sama sinergis antar pelaku industri minyak Atsiri maupun dengan pemerintah daerah setempat serta mitra usaha lainnya, kualitas sumberdaya manusianya ditinjau dari motivasi dan inovasi masih rendah, dan kepekaan dan kemampuan menangkap peluang usaha berbasis potensi lokal terkait dengan produksi minyak Atsiri Kenanga masih relatif terbatas. Dari uraian di atas perlu kiranya sentuhan rekayasa sosial dan rekayasa teknologi untuk mengatasi persoalan tersebut.

Penelitian ini bertujuan untuk melakukan rekayasa sosial dan teknologi untuk mengatasi 
persoalan yang dihadapi industri minyak Atsiri di kabupaten Blitar. Rekayasa Sosial secara konseptual berkaitan dengan konsep development. Development adalah proses sosial yang direncanakan atau direkayasa di antaranya melalui rekayasa ekonomi, sebagai bagian dari rekayasa sosial (Jalaludin, 2000). Rekayasa ekonomi pada program ini diprioritaskan bagi masyarakat pelaku industri minyak Atsiri (non corporate), yaitu suatu program yang meningkatkan produktivitas dan perluasan pemasaran produk. Dalam Rekayasa sosial diperlukan adanya pembangunan mentalitas masyarakat agar terbentuk karakter diri sebagai bangsa yang memiliki daya saing. Sedangkan rekayasa teknologi dalam program ini diharapkan dapat meningkatkan produksi baik dari segi kuantitas, kualitas maupun kontinyuitas, sehingga terjadi peningkatan pendapatan atau keuntungan. Diperlukan pula kegiatan pemberdayaan masyarakat melalui introduksi teknologi dan intervensi sosial dalam menunjang peningkatan SDM, produksi dan pemasaran sehingga memenuhi target yang dicanangkan oleh Pemerintah Kabupaten Blitar, baik dalam skala nasional maupun skala internasional. Hasil dari program pengembangan industri non-corporate ini diharapkan dapat meningkatkan motivasi pelaku industri minyak Atsiri Kenanga, meningkatkan produktivitas minyak Atsiri baik secara kuantitas maupun kualitas, memberi penguatan kelembagaan sosial melalui pembentukan cluster-cluster industri di tingkat komunitas petani.

\section{METODE}

Menurut Prijono dan Pranaka (1996) lahirnya konsep pemberdayaan sebagai antitesa terhadap model pembangunan yang memihak pada rakyat. Konsep ini mememiliki kerangka logis sebagai berikut: (1) proses pemusatan kekuasaan terbangun dari pemusatan kekuasaan faktor produksi (2) pemusatan kekuasaan faktor produksi akan melahirkan masyarakat pekerja dan masyarakat pengusaha pinggiran (3) kekuasaan akan membangun bangunan atas atau sistem pengetahuan, sistem politik, sistem hukum dan sistem ideologi yang manipulatif untuk memperkuat legitimasi dan (4) pelaksanaan sistem pengetahuan, sistem politik, sistem hukum dan sistem ideologi secara sistematik akan menciptakan dua kelompok masyarakat, yaitu masyarakat berdaya dan masyarakat tunadaya. Masyarakat yang tunadaya inilah yang kemudian mendapatkan perhatian untuk diberdayakan melalui sejumlah program sebagai implementasi dari berbagai konsep dan pendekatan pemberdayaan. Friedman (1992) menyebutkan bahwa pemberdayaan lebih ditekankan kepada keutaman politik melalui otonomi pengambilan keputusan untuk melindungi kepentingan rakyat yang didasarkan pada sumber daya pribadi dan melalui partisipasi. Sedangkan pengertian partisipatif integratif diambil dari Salviana (2008) yaitu pemberdayaan dengan melibatkan banyak pihak yang terkait dengan tujuan dalam memberikan bekal dan penyadaran kemampuan diri serta pemberdayaan yang meningkatkan motivasi dan keterampilan usaha produktif agar dapat meningkatkan kesejahteraan dan pendampingan serta perlindungan/jaminan hidup.

Pendekatan yang digunakan dalam penelitian ini adalah pemberdayaan masyarakat dengan model partisipatif integratif yaitu pemberdayaan dengan melibatkan partisipasi masyarakat secara terpadu. Langkah yang digunakan dalam pelaksanaan kegiatan ini secara komprehensip, agar dapat bermanfaat bagi pengguna yakni analisa SWOT dan need assessment. Kegiatan ini terpadu sejak sisi hulu hingga hilir tetapi lebih fokus pada sisi prosessing dan industri hilir.

Langkah atau tahapan pelaksanaan penelitian ini, mengutamakan keterlibatan dan partisipasi masyarakat/pelaku pengguna dalam lingkup cluster agro industri minyak Atsiri secara terpadu/integratif. Integrasi yang dimaksud ini meliputi aspek teknologi, kelayakan finansial, manajerial, pemasaran dan rekayasa sosial. Rekayasa sosial ini diperlukan karena penyempurnaan teknologi dan penguatan aspek manajerial saja dirasa masih kurang, karena keberlangsungan usaha sangat dipengaruhi oleh kompetensi SDM dari masyarakat pengguna, khususnya yang berkaitan langsung di lini terdepan agro industri ini.

Penelitian ini dilaksanakan efektif dengan tata laksana penelitian untuk penyempurnaan teknologi sebagai berikut: Pertama, penelusuran berbagai informasi dan kepustakaan. Pada tahap ini dilakukan penelusuran berbagai informasi dan kepustakaan yang terkait antara lain dengan teknologi produksi minyak Atsiri (kenanga), aspek sosial, ekonomi dan budaya masyarakat serta identifikasi geografis wilayah maupun potensi ketersediaan sumberdaya agro industri minyak Atsiri. Kedua, survei lapangan, observasi dan pengkajian teknologi proses. Pada tahapan ini dikaji berbagai aspek yang menyangkut kondisi proses produksi, permasalahan mutu, produk minyak Atsiri serta evaluasi sistem, fasilitas dan peralatan produksi minyak Atsiri masyarakat yang merupakan bagian dari audit teknologi alam pengolahan minyak Atsiri (Djajadiningrat et al., 2007). Ketiga, pengkajian 
Alternatif Metode Perbaikan Teknologi. Pada tahap ini, dikaji berbagai alternatif metode yang mungkin ditempuh untuk perbaikan proses pengolahan minyak Atsiri masyarakat serta hal-hal yang perlu dipertimbangkan pada saat implementasi. Selanjutnya dilakukan penentuan bobot kriteria serta penilaian masing-masing alternatif berdasarkan kriteria yang telah ditentukan tersebut. Keempat, Pengkajian Prioritas Kebutuhan Mesin dan Peralatan untuk Pengolahan Minyak Atsiri yang lebih Baik. Setelah mengkaji berbagai alternatif metode untuk perbaikan teknologi dan identifikasi kebutuhan mesin/peralatan yang diperlukan pada masing-masing tahap proses pengolahan minyak Atsiri, maka perlu pengadaan boiler untuk memproduksi steam.

Aspek sosial, ekonomi dan manajerial dalam penelitian ini, dikembangkan melalui kajian terhadap berbagai aspek dan melalui evaluasi diri dengan pendekatan analisis SWOT/K2PA (kekuatan, keterbatasan, peluang dan ancaman), sehingga dengan evaluasi diharapkan dapat membaca peluang (kesempatan), meniadakan kelemahan, memanfaatkan kekuatan dan mengantisipasi ancaman).

Di sisi lain, pendekatan/konsep cluster digunakan untuk merujuk pada kelangsungan usahanya dengan menitik beratkan pada sistim terpadu keterkaitan ke depan (forward) dan ke belakang (backward linkaged) dengan baik untuk membangun pelaku bisnis kecil di kawasan atau sentra dengan menciptakan dinamika cluster melalui instrumen dukungan finansial dan non finansial.

\section{HASIL DAN PEMBAHASAN}

Di kabupaten Blitar telah dilaksanakan berbagai strategi pelembagaan industrialisasi diawali dengan langkah pemberdayaan yang terintegrasi dengan kebijakan industri yang tertuang dalam Renstra Pemerintah Daerah Kabupaten Blitar. Pendekatan Integratif yang dilaksanakan dalam program pemberdayaan ini juga menunjukkan usaha berbagai lembaga untuk membentuk kerja sama antara para pelaku industri Atsiri dengan pemerintah, dan institusi lain seperti Bappeda, Dewan Atsiri dan Perhutani lewat PHBM (Pengelolaan Hutan Bersama Masyarakat). Hal ini sejalan dengan tujuan program "Putri Kencana" di Kabupaten Blitar, yaitu: (1) Menanggulangi kemiskinan, menurunkan pengangguran, dan meningkatkan kesejahteran masyarakat melalui pertumbuhan ekonomi dan perluasan kesempatan kerja dipedesaan, (2) Menciptakan pemerataan dan memperkecil kesenjangan sekaligus menciptakan hubungan saling menguntungkan antar desa dengan desa lainnya dalam satu kecamatan, (3) Mendorong terciptanya hubungan kerja sama yang harmonis antara pemerintah, dunia usaha dan masyarakat di tingkat kecamatan yang saling menguntungkan.

\section{Penyempurnaan Destilasi Minyak Atsiri Sistem Uap}

Destilasi merupakan proses pemisahan komponen yang mudah menguap dari komponen yang tidak menguap atau proses pemisahan dari suatu campuran yang bersifat mudah menguap. Destilasi dapat dilakukan dengan berbagai cara yaitu: Simple distilation, fraksional distilation, flash distilation, dan molekuler distilation. Destilasi yang digunakan pada penyuling di Blitar adalah water distilation.

Proses destilasi minyak Atsiri dengan water distilation menghasilkan kualitas minyak Atsiri yang cukup rendah, kadar minyaknya sedikit, terkadang terjadi proses hidrolisis asam, dan produk minyaknya bercampur dengan hasil sampingan. Untuk itu, perlu dilakukan pengambilan minyak Atsiri dengan menggunakan metode destilasi uap. Kualitas produk minyak Atsiri yang dihasilkan menggunakan metode destilasi ini, jauh lebih sempurna dibandingkan dengan cara water distillation, sehingga harga jualnya pun jauh lebih tinggi. Metode yang sudah dilakukan di Kabupaten Blitar, memiliki beragam kapasitas produksi dan juga beragam kualitas hasil minyak Atsiri. Lamanya waktu yang dibutuhkan untuk proses destilasi, juga cukup panjang, sekitar 62 jam sekali proses produksi.

Alat penyuling dimodifikasi pada bagian boiler untuk mensuplai api/panas ke alat-alat penyuling seperti ditunjukkan pada gambar 1. Cara kerja alat ini dapat mampu menghasilkan perbaikan proses penyulingan sehingga menghemat bahan bakar dan tenaga kerja berikut tabel 1 dan 2 menunjukkan perbandingan penyulingan sebelum dengan sesudah inovasi teknologi boiler.

\section{Pelatihan Motivation Building}

Pelatihan ini diikuti oleh para petani, pemetik bunga kenanga, pedagang, pengepul dan penyuling minyak atsiri. Pelatihan ini ditujukan untuk membangun dan memperkuat motivasi peserta dalam melestarikan industri minyak Atsiri berbasis kenanga. Pelatihan ini sangat diperlukan karena kepedulian komunitas petani, pemetik, pedagang dan pengepul bunga kenanga terhadap pelestarian dan budidaya tanaman, pohon kenanga ditengarai mengalami penurunan. Hasil dari pelatihan ini, peserta semakin sadar untuk bersinergi dalam melestarikan dan meningkatkan budidaya tanaman kenanga serta meningkatkan usaha pada sektor industri berbasis bunga kenanga. 

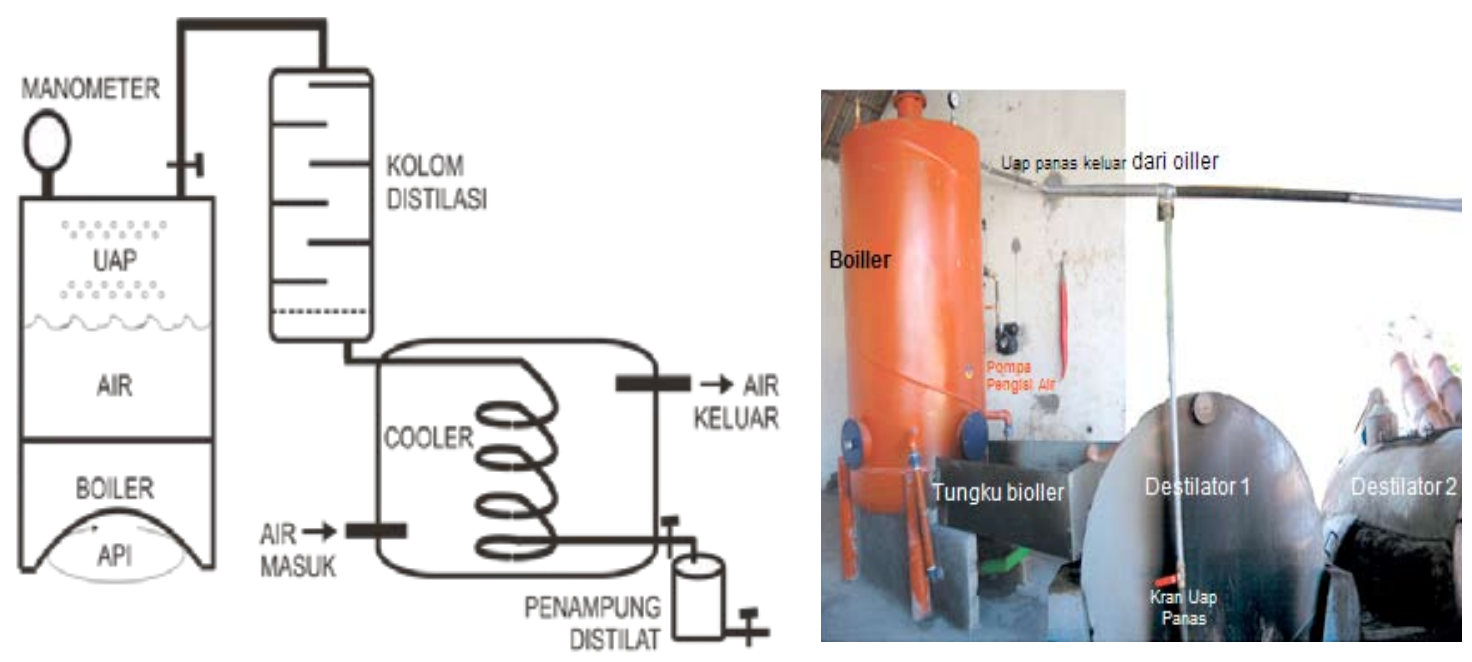

Gambar 1. Rekayasa Boiler untuk Destilasi Minyak Atsiri Kenanga

Tabel 1. Hasil Destilasi Minyak Kenanga Sebelum Menggunakan Inovasi Boiler

\begin{tabular}{ccccc}
\hline No. & $\begin{array}{c}\text { Berat } \\
\text { Bunga } \\
(\mathbf{k g})\end{array}$ & $\begin{array}{c}\text { Berat } \\
\text { Minyak } \\
(\mathbf{k g})\end{array}$ & $\begin{array}{c}\text { Rendemen } \\
\mathbf{( \% )}\end{array}$ & $\begin{array}{c}\text { Lama } \\
\text { Proses } \\
\text { (jam) }\end{array}$ \\
\hline 1 & 687,5 & 10,8 & 1,571 & 62 \\
2 & 700,5 & 11,2 & 1,599 & 62 \\
3 & 734,0 & 11,1 & 1,512 & 62 \\
4 & 713,0 & 11,0 & 1,543 & 62 \\
5 & 740,5 & 12,2 & 1,648 & 62 \\
6 & 730,5 & 12,2 & 1,670 & 62 \\
7 & 688,0 & 9,6 & 1,395 & 62 \\
8 & 708,0 & 9,4 & 1,328 & 62 \\
9 & 708,0 & 9,5 & 1,342 & 62 \\
10 & 735,0 & 9,5 & 1,293 & 62 \\
11 & 715,0 & 12,1 & 1,692 & 62 \\
12 & 642,0 & 8,6 & 1,340 & 62 \\
\hline Rata-rata & $\mathbf{7 0 8 , 5}$ & $\mathbf{1 0 , 6}$ & $\mathbf{1 , 4 9 4}$ & $\mathbf{6 2}$ \\
\hline
\end{tabular}

Tabel 2. Hasil Destilasi Minyak Kenanga Sesudah Menggunakan Inovasi Boiler

\begin{tabular}{ccccc}
\hline No. & $\begin{array}{c}\text { Berat } \\
\text { Bunga } \\
\mathbf{( k g )}\end{array}$ & $\begin{array}{c}\text { Berat } \\
\text { Minyak } \\
(\mathbf{k g})\end{array}$ & $\begin{array}{c}\text { Rendemen } \\
(\%)\end{array}$ & $\begin{array}{c}\text { Lama } \\
\text { Proses } \\
(\mathbf{j a m})\end{array}$ \\
\hline 1 & 587 & 9,9 & 1,687 & 48 \\
2 & 751 & 12,5 & 1,664 & 48 \\
3 & 642 & 11,2 & 1,745 & 48 \\
4 & 691 & 12,2 & 1,766 & 48 \\
5 & 637 & 12,4 & 1,947 & 48 \\
6 & 744 & 13 & 1,747 & 48 \\
7 & 668 & 11,7 & 1,751 & 48 \\
8 & 644 & 12,1 & 1,879 & 48 \\
9 & 690 & 11,3 & 1,638 & 48 \\
10 & 675 & 11,5 & 1,704 & 48 \\
11 & 628 & 11,3 & 1,799 & 48 \\
12 & 653 & 11,6 & 1,776 & 48 \\
\hline Rata-rata & $\mathbf{6 6 7 , 5}$ & $\mathbf{1 1 , 7 2 5}$ & $\mathbf{1 , 7 5 9}$ & $\mathbf{4 8}$ \\
\hline
\end{tabular}

\section{Pembuatan Pupuk Organik Hayati Secara Sederhana}

Tahapan pembuatan pupuk organik adalah sebagai berikut: Pertama, menyiapkan tempat pembuatan di sekitar lahan petani, agar pupuk yang telah difermentasi mudah untuk diaplikasi pada lahan. Kedua, campuran bahan kotoran ternak dan sisa tanaman diaduk merata dengan ditambahkan agen hayati. Ketiga, kadar air dipertahankan 40-60\%, sebelum pengomposan bahan dites lebih dulu. Keempat, menutup rapat dengan plastik/karung/ dedaunan. Terakhir, setelah 5 hari, tutup dibuka dan bahan diaduk/dibalik merata dan ditutup kembali (dilakukan 3-5 kali sampai bahan tidak berbau dan tidak lengket). Bahan yang jadi, sebelum digunakan diangin-anginkan terlebih dulu selama 1 hari.

Berikut ini adalah gambar tahapan proses pengolahan limbah padat dari industri minyak Atsiri, menjadi pupuk organik padat:

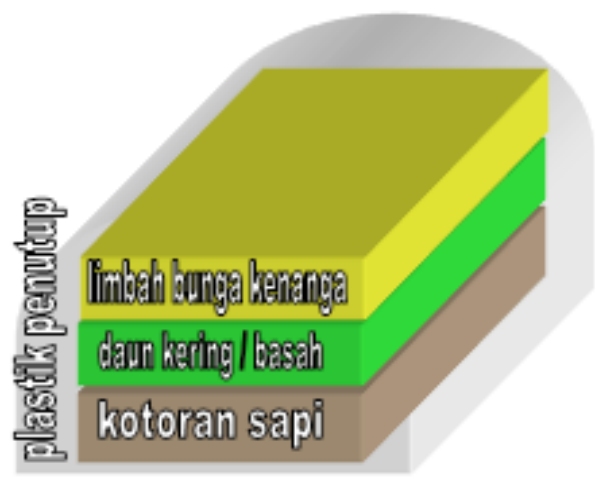

Gambar 2. Tahapan Proses Pengolahan Limbah Padat Menjadi Pupuk Organik Padat 


\section{Pembuatan Pupuk Organik Cair Hayati menggunakan Mikroba Aktivator}

Tahapan proses pembuatan pupuk organik cair adalah sebagai berikut: (1) larutan mikroba activator, gula, air dicampur merata, (2) jerami, daun hijau yang telah digiling, dedak, tepung ikan dicampur merata, (3) bahan dari hasil tahap ke-2 dimasukkan dalam fermentor, kemudian disiram dengan larutan dari hasil tahap ke-1 sebanyak 5-10\%. Pencampuran dilakukan perlahan-lahan dan merata, (4) fermentor ditutup dan diberi ventilasi untuk mengeluarkan gas amoniak dan metan. Fermentasi diakhiri, setelah produksi gas metan atau amoniak berhenti, (5) proses fermentasinya berlangsung lama sekitar 14-29 hari. Terakhir, cairan atau lindi dikeluarkan dari fermentor dan ditampung dalam botol digunakan sebagai pupuk cair hayati dan siap diaplikasikan pada tanaman. Berikut ini adalah gambar tahapan proses pengolahan limbah padat dari industri minyak Atsiri, menjadi pupuk organik cair:

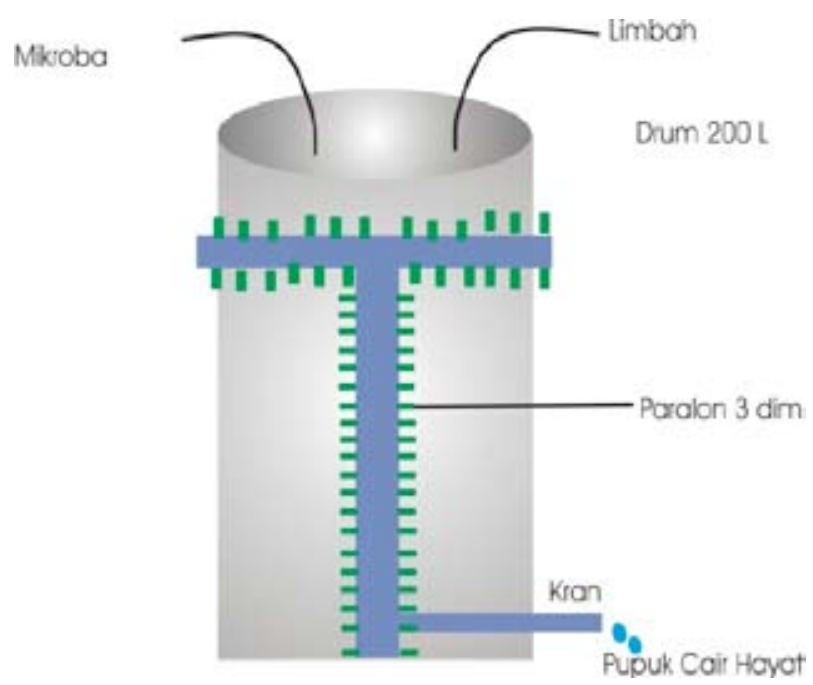

Gambar 3. Tahapan Proses Pengolahan Limbah Padat Menjadi Pupuk Organik Cair

\section{Pembuatan Minyak Gosok dan Formula Minyak Aroma Terapi}

Obat tradisional adalah bahan atau ramuan bahan yang berupa bahan tumbuhan, bahan hewan, bahan mineral, sediaan galenik atau campuran dari bahan-bahan tersebut, yang secara tradisional telah digunakan untuk pengobatan berdasarkan pengalaman. Parem atau param adalah usaha peracikan, pencampuran, pengolahan dan pengedaran obat tradisional dalam bentuk cairan tanpa penandaan dan atau merk dagang serta dijajakan untuk langsung digunakan.

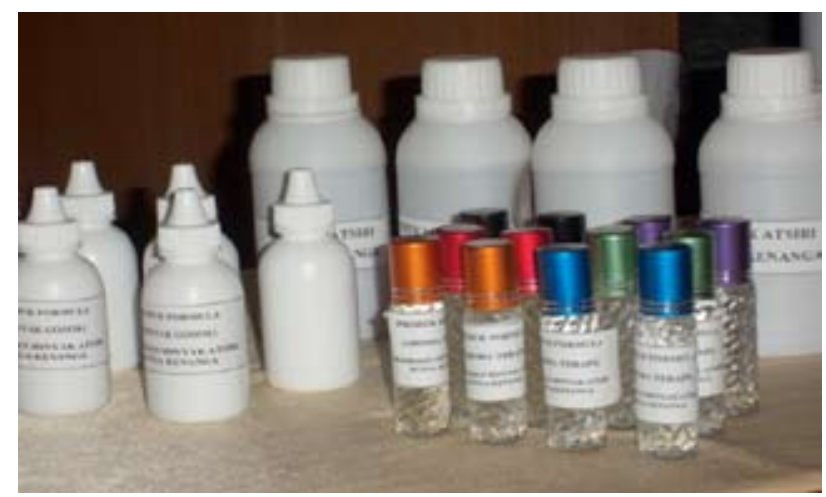

Gambar 4. Minyak Gosok dan Aroma Therapy dalam Kemasan

\section{Industri non-corporate menuju Pembangunan Karakter Bangsa}

Sebelum dibentuk kelompok usaha kecil, dilakukan pelatihan pembuatan laporan keuangan secara sederhana dan juga pelatihan pengelolaan SDM. Pelatihan pembuatan laporan keuangan ini berisi tentang bagaimana pentingnya pemahaman kelompok usaha kecil untuk menganalisis alur finansial mulai dari perencanaan belanja bahan, biaya produksi dan keuntungan. Setelah pelatihan tersebut di atas terbentuk 3 (tiga) kelompok usaha kecil yang tidak berbasis corporate, tetapi berbasis pada potensi masyarakat dalam hal ini komunitas bunga kenanga baik, petani, pemetik dan pedagang yang berminat pada pembuatan pupuk atau minyak gosok/aroma therapy berbahan dasar minyak Atsiri kenanga. Dua kelompok bermitra dengan satu penyuling (pelaku industri Atsiri kenanga) dan satu kelompok lagi bermitra dengan penyuling lainnya. Kelompok ini merupakan cikal bakal pembentukan cluster agar dalam proses selanjutnya dapat memperkuat kelembagaan ekonomi di tingkat lokal. Untuk lebih jelasnya dapat dilihat skema mata rantai proses produksi industri minyak Atsiri kenanga dan hubungannya dengan ketiga kelompok tersebut sebagai berikut:

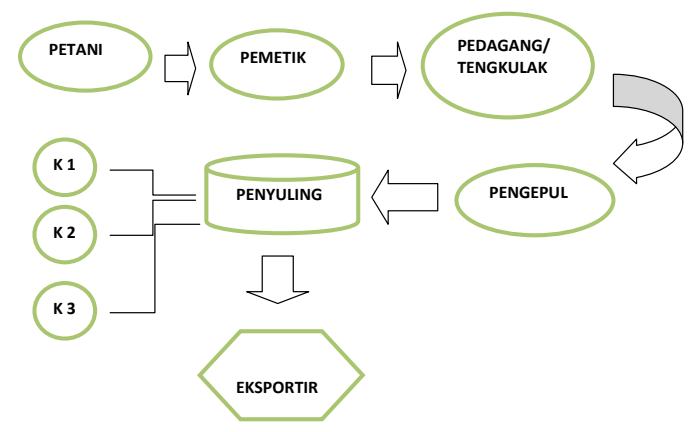

Gambar 5. Mata Rantai Proses Produksi Industri Minyak Atsiri Kenanga 


\section{SIMPULAN}

Pemberdayaan masyarakat partisipatif integratif pada industri non-corporate pada komunitas Atsiri kenanga di kecamatan Srengat Kabupaten Blitar ini adalah suatu model pemberdayaan yang sangat sesuai bagi pengembangan industri di pedesaan. Beberapa aktivitas dalam penelitian ini adalah bantuan penyempurnaan teknologi mesin boiler yang membantu efisiensi dalam proses penyulinganminyak Atsiri baik waktu penyulingan maupun efisiensi penggunaan bahan bakar, mengolah limbah industri penyulingan, membuat usaha minyak gosok/aroma therapy, penguatan pelembagaan ekonomi dengan kelompok usaha industri non-corporate menjadi alternatif pilihan yang dipandang tepat untuk komunitas petani bunga kenanga sehingga mampu menciptakan pelaku industri kecil dan menengah lebih percaya diri dan memiliki karakter bangsa yang berdaya saing bukan hanya di tingkat nasional tetapi juga internasional.

\section{DAFTAR PUSTAKA}

Djajadiningrat, Mukti Rahardjo Wibowo, 2007. Audit Teknologi. Pengertian dan pedoman pelaksanaannya, PAT-BPPT, Jakarta.

Friedman, J., 1992. Empowerment The Politics of Alternative Development, Blackwell Publishers: Cambridge: USA.

Jalaluddin, R., 2000. Rekayasa Sosial: Reformasi, Revolusi atau Manusia Besar?, Penerbit Remadja Rosdakarya, Bandung.

Salviana, V., 2009. Pemberdayaan Perempuan Usia Produktif melalui Pengembangan Model Life Skill (Pendidikan Kecakapan Hidup) Berbasis Potensi Lokal, Laporan Penelitian Hibah Bersaing, tidak dipublikasikan.

Studi Kawasan Pengembangan Ekonomi Terpadu Kabupaten Blitar Tahun 2007.

www. Blitar Kab.go.id/puteri kencana, diakses 21 Februari 2011. 